\title{
THE EFFECT OF SPIRITUAL INTELLIGENCE (SQ) AND PERSONALITY TYPES ON AUDITOR'S ABILITY TO DETECT FRAUD
}

\author{
Romy Andriyanto*), Effriyanti, Angga Hidayat \\ Accounting Department University of Pamulang \\ *Email : romy.andriyanto125@gmail.com
}

\begin{abstract}
Nowadays, the recruitment of an auditor is still based on the intellectual intelligence to assess whether a person is eligible to be an auditor or not. The purpose of this study is to recognize the effect of spiritual intelligence and personality types on auditor ability to detect fraud at public accountant office in South Jakarta. The population of the study are the auditors who work in Public Accounting Firm in South Jakarta. The sample selection is conducted by convenience sampling method. There are 8 Public Accounting Firms in South Jakarta area which fulfill the criteria as research sample, then the questionnaires distributed are 85 data. However, the questionnaires that meet the criteria are 75 data. Consequently, those 75 data can be further processed by using multiple linear regression. The results of the study indicate that: (1) Spiritual Intelligence (SQ) has a significant effect on the ability of Auditors in Detecting fraud with Sig. 0.000 (0,000 <0,05), (2) Personality Type has no significant effect on Auditor's Ability in Detecting fraud with sig value. 0,654 (0,654> 0,05), and Spiritual Intelligence (SQ) and Personality Type simultaneously have a significant effect on Auditor's Ability to Detect fraud with the sig value. $0.000(0,000<0.05)$.
\end{abstract}

Keywords : Spiritual Intelligence (SQ), Personality Types, Auditor's Ability to Detect Fraud

\begin{abstract}
Abstrak
Saat ini, perekrutan auditor masih didasarkan pada kecerdasan intelektual untuk menilai apakah seseorang memenuhi syarat untuk menjadi auditor atau tidak. Tujuan penelitian ini adalah untuk mengetahui pengaruh kecerdasan spiritual dan tipe kepribadian terhadap kemampuan auditor untuk mendeteksi kecurangan di kantor akuntan publik di Jakarta Selatan. Populasi penelitian adalah auditor yang bekerja di Kantor Akuntan Publik di Jakarta Selatan. Pemilihan sampel dilakukan dengan metode convenience sampling. Ada 8 Kantor Akuntan Publik di wilayah Jakarta Selatan yang memenuhi kriteria sebagai sampel penelitian, kemudian kuesioner yang disebar 85 data. Namun, kuesioner yang memenuhi kriteria adalah
\end{abstract}


75 data. Akibatnya, 75 data tersebut dapat diproses lebih lanjut dengan menggunakan regresi linier berganda. Hasil penelitian menunjukkan bahwa: (1) Spiritual Intelligence (SQ) memiliki pengaruh yang signifikan terhadap kemampuan Auditor dalam mendeteksi kecurangan dengan Sig. 0,000 (0,000 $<0,05)$, (2) Personality Type tidak berpengaruh signifikan terhadap Kemampuan Auditor dalam mendeteksi kecurangan dengan nilai sig. 0,654 (0,654>0,05), dan Spiritual Intelligence (SQ) dan Tipe Kepribadian secara bersamaan memiliki pengaruh yang signifikan terhadap Kemampuan Auditor untuk Mendeteksi penipuan dengan nilai sig. $0,000(0,000<0,05)$.

Kata Kunci: Kecerdasan Spiritual (SQ), Tipe Kepribadian, Kemampuan Auditor untuk Mendeteksi Penipuan

\section{INTRODUCTION}

Audit activity of company's financial statements become one of the most important tasks of an auditor. The auditor performs his/ her duty in a company that sells its stock to the public. As a result, the users of information, namely creditors, investors, and others will be greatly influenced by public accountant before they decide or give their trust about the company.

Moreover, the problems discussed in the study are two possibilities, namely the negligence and fraud. Negligence is negligent factor and not done intentionally. However, fraud is done consciously or deliberately. The intelligence of an auditor can assist the auditor in solving the problems that they face. Intelligence is divided into 3 (three) namely Intelligence Quotients (IQ), Emotional Quotients (EQ), and Spiritual Quotients (SQ). Commonly, Intelligence Quotients (IQ) is assumed to be a factor to one's success, while others support that Spiritual Quotients (SQ) is an intelligence that has a great influence in supporting the performance of the other intelligences since it is the control of the other intelligences. Spiritual intelligence is not related to religion but the presence of one's religion can help to improve spiritual intelligence.

The auditors are widely known as individuals who are skeptical, have critical thinking and have a high intelligence. With attitudes inherent to an auditor whether he/ she wants to be an auditor or not should have a specific criteria of personality type individually. As a consequence, auditor has almost identical personalities each other. The study will be divided into 5 sections. Specifically, part 1 for introduction, part 2 for literature review, section 3 for data research methods, Section 4 for research results and Section 5 for the conclusions of the study. 
Vol.1, No.3, Sept 2018

\section{LITERATURE REVIEW}

\subsection{Theoretical Review}

\subsubsection{Cognitive Dissonance Theory}

Cognitive dissonance theory was developed by Leon Festinger in 1957. This theory says that humans are basically fond of consistency, therefore humans will tend to take non-contradictory attitudes and avoid taking actions that do not have appropriate to their attitudes.

In relation to the study, this theory explains the attitude of the auditor's personality according to cognitive dissonance when detecting fraud. Furthermore, a high level of trust of the client will affect the auditor's personality to the client.

\subsubsection{Fraud}

Fraud is an action conducted by a single person or in a group that aims to take an advantage tends to harm others. There are three occasions that encourage fraud, namely the drive that causes a person to do fraud (pressure), opportunities that allow fraud occurs (opportunity), and an important element in fraud, namely perpetrators seek justification for their action (Nasution, 2012: 6).

\subsubsection{Spiritual Quotients}

Intelligence is one of the greatest gifts that Allah provides to humans. Because of the intelligence, human beings become the best creature compared with others on earth. Intelligence may include creativity, personality, character, knowledge, or wisdom. Intelligence oftentimes refers to the ability or mental capacity in thinking and acting. With the intelligence, people can maintain and improve the quality of life through the process of thinking and learning continuously.

Spiritual intelligence is the intelligence that helps one to develop himself/ herself as a whole through the possibility of applying positive values. SQ is a facility that helps one to overcome problems and make peace with the problem. The main feature of this SQ is shown by one's consciousness to use his/hee experience as a form of application of value. A well-developed spiritual intelligence will be characterized by a person's ability to be flexible and adaptable to the environment, have a high level of awareness, be able to deal with suffering and pain, be able to take valuable lessons from a failure, be able to live according to the vision and mission, be able to see the relationship among various things, independent, and understand the meaning of life.

\subsubsection{Ability to Detect Fraud}

The auditor's ability to detect fraud is the quality of an auditor in explaining the inadequacy of the financial report presented by the company with identifying and proving the fraud. Nasution (2012:7) stated that the task of fraud detection is an unstructured task that requires the auditor to produce alternative methods and to seek additional information from various sources. In detecting fraud, the auditor is required to have some capabilities that can support him/her in detecting fraud, such as (1) technical skills including audit competence, information technology and investigative skill, (2) capability to work in a team, the auditor should be able to accept other people's ideas, can communicate with others well and (3) 
mentoring skill, this capability must be owned by a senior auditor then a senior can guide his/her junior during investigation process.

\subsection{Hyphotesis Development}

2.2.1 The Effect of Spiritual Intelligence (SQ) on the ability of auditors to Detect Fraud

The manifestation of spiritual intelligence is a good attitude that is perceived by the perpetrator. Agoes and Ardana (2011: 19) stated that people who have high spiritual intelligence certainly have high ethical behavior as well. If the SQ auditor has scandal and manipulation performed by the auditor, then he/ she has no good ethical behavior (Ramantha, 2013: 496).

Spiritual intelligence can affect ethical behavior through allowing for insight and understanding to find meaning in one's existence, a place to act, to think, and to feel. Hypothesis proposed in this research is:

$\mathrm{H}_{1}$ : $\quad$ Spiritual Intelligence (SQ) affects the auditor's ability to detect fraud.

2.2.2 The effect of Personality Types on Auditor's Ability to Detect Fraud

Ismail (2015: 265) mentioned that personality type affects one's decision. The type of personality affects the general orientation towards achievement and purpose, alternative selection, action to risk, and reaction under pressure. This type of personality affects the ability of decision-makers to obtain large amounts of information, time pressure, and self-defense. Hypothesis proposed in the study is:

$\mathrm{H}_{2}$ : Personality types affect the auditor's ability to detect fraud

2.2.3 The Effect of Spiritual Intelligence (SQ), and Personality Types to Auditor's Ability to Detect Fraud

Spiritual intelligence and personality type are related to each other. These two factors can make easier for auditors to face very difficult decisions even if they can help calm down and make decisions appropriately. Two of them have the same strength in shaping the character of an auditor, either an honest or dishonest auditor, in relation to the auditor's ability to detect fraud. Hypothesis proposed in the study is:

$\mathrm{H}_{3}$ : Spiritual intelligence and personality types affect the auditor's ability to detect fraud

\section{RESEARCH METHODOLOGY}

\subsection{Type and Location of Research}

The type of the study used is quantitative. The data in the study is the primary data, by filing a questionnaire to auditors who work in Public Accounting Firm at South Jakarta.

\subsection{Population and Sample of Research}

The authors decide population of the study are senior and junior auditor in Public Accounting Firm (KAP) at South Jakarta. The total number of registered Public Accounting Firm at South Jakarta are 73 offices. The sempling method 
used is non-probability method, namely convenience sampling by giving the questionnaire to Public Accounting Firm (KAP).

Sample of the study is the auditors working in Public Accounting Firm at South Jakarta. the researchers spread questionnaires to 8 (eight) Public Accounting Firms.

\subsection{Data Analysis Method}

Data analysis method in the study is quantitative by using SPSS 22 program as a application used to test the data.

\subsubsection{Descriptive statistics}

Descriptive statistics is used to provide information about characteristics of the research variables and respondents' demographic lists. Descriptive statistics give descriptive or descriptions of data seen on mean, standard deviation, variant, maximum, minimum, sum, range, kurtosis and skewness (Ghozali, 2009: 19).

\subsubsection{Pilot Test}

Pilot test or pilot study is a feasibility study, or a small version in a study conducted for preparation in a larger study. The pilot test is used to determine whether previous research about the effect of spiritual intelligence on audit quality written by Muhammad Fadjar Arif Fauzan in 2017 can be used as questionnaires and indicators in this study or not.

\subsubsection{Data Quality Test}

1) Validity test is used to determine whether the research questionnaire is valid or not. Test is done by comparing the coefficient $r$ test with coefficient $r$ table.

2) Reliability Test is used to measure the research questionnaire. According to Ghozali (2011: 153), the questionnaire is said to be reliable if one's answer to the question is consistent or stable over time.

\subsubsection{Classical Assumption Test}

1) Multicolinearity Test

multicollinearity test is needed to determine whether there is an independent variable that has similarities with other independent variables in one model or not. The similarity among independent variables in one model will lead to a very strong correlation between an independent variable with another independent variable.

2) Normality Test

According to Ghozali (2009: 147), normality test aims whether regression model of the dependent variable and independent variable have a contribution or not.

3) Heteroscedasticity Test

The heteroxidity test aims to test whether there is an inequality variance of one observation residual to other observations.

\subsection{5. hypothesis testing}

1) Determination Coefficient Test

Determination Coefficient Test is to test how far the research model in explaining the dependent variable by calculating the coefficient of determination.

2) F test 
F test basically shows whether all independent variables referred to the study are simulat a significant explanation on the dependent variable or not

3) T test

According to Sudaryanto (2011: 45), the statistical test t basically shows how far the influence of one independent variable individually in explaining the dependent variable.

\section{RESULTS AND DISCUSSION}

\subsection{Overview of Research Objects}

The data of the study were collected by distributing questionnaires in October 2017 to auditors at the Public Accounting Firm (KAP) in South Jakarta. In the study there are 8 (eight) Public Accounting Firms and as many as 85 questionnaires distribute to eighth offices. Henceforth, 75 questionnaires only were used as research data. The table below is a general description of the questionnaires submitted and received from the Public Accounting Firms:

\begin{tabular}{|c|l|c|c|}
\hline N0 & \multicolumn{1}{|c|}{ KETERANGAN } & $\begin{array}{c}\text { Sampel yang tidak } \\
\text { digunakan }\end{array}$ & $\begin{array}{c}\text { Sampel yang } \\
\text { digunakan }\end{array}$ \\
\hline 1 & Kuisioner yang disebar & - & 85 \\
\hline 2 & Kuisioner yang kembali & - & 85 \\
\hline 3 & Kuisioner yang tidak bisa diolah & 5 & 80 \\
\hline 4 & Kuisioner yang tidak lengkap & 2 & 78 \\
\hline 5 & Kuisioner yang tidak kembali & 3 & 75 \\
\hline \multicolumn{3}{|c|}{ Total kuisioner yang dapat diolah } & 75 \\
\hline
\end{tabular}

\subsection{Descriptive Test}

Descriptive statistical test is used to provide a statistical description of the independent variables and dependent variables of the study. Description of data presented include the value of Mean (M), Median (Me), Mode (Mo), and Standard Deviation (SDi).

Descriptive Statistics Table

\begin{tabular}{|l|r|r|r|r|r|}
\hline & N & Minimum & Maximum & Mean & Std. Deviation \\
\hline Kecerdasan Spiritual & 75 & 30 & 43 & 35.72 & 3.096 \\
Tipe Kepribadian & 75 & & 1 & .79 & .412 \\
Kemampuan Auditor dalam & & & & & \\
Mendedeteks Kecurangan & 75 & 34 & 52 & 39.52 & 3.550 \\
Valid N (listwise) & 75 & & & & \\
\hline
\end{tabular}

\begin{tabular}{|c|l|c|c|c|}
\hline No & \multicolumn{1}{|c|}{ Variabel } & Cronbach's Alpha & Kriteria & Keterangan \\
\hline 1 & Kecerdasan Spirtual (SQ) & 0,755 & 0,7 & Reliabel \\
\hline 2 & Tipe Kepribadian & 0,71 & 0,7 & Reliabel \\
\hline 3 & $\begin{array}{l}\text { Kemampuan Auditor } \\
\text { dalam Mendeteksi } \\
\text { Kecurangan }\end{array}$ & 0,701 & 0,7 & Reliabel \\
\hline
\end{tabular}

\subsection{Pilot Test}

Prior to conducting research on auditors in South Jakarta, the authors conducted a pilot test that was deployed on 02 October 2017 for the needs of this 
study. Pilot test will test the quality of data namely the test of validity and reliability test.

The pilot test questionnaire was taken from a previous study from Muhammad Fadjar Arif Fauzan (2016), entitled "The Effect of Emotional Intelligence, Spiritual Intelligence, and Client Pressure on Audit Quality" using representative sample criteria. The pilot test used a sample of 25 respondents from Pamulang University semester 7 and 8 majoring in Audit.

\begin{tabular}{|c|c|c|c|c|}
\hline N0 & KETERANGAN & $\begin{array}{c}\text { Jumlah } \\
\text { Kuisioner } \\
\text { Dikirim }\end{array}$ & $\begin{array}{c}\text { Jumlah } \\
\text { Kuisioner } \\
\text { Kembali }\end{array}$ & $\begin{array}{c}\text { Jumlah } \\
\text { Kuisioner } \\
\text { yang Layak }\end{array}$ \\
\hline \multicolumn{5}{|l|}{ Universitas Pemulang } \\
\hline 1 & Kuisioner di kelas Regular A & 10 & 10 & 10 \\
\hline 2 & Kuisioner di kelas Regular B & 10 & 10 & 10 \\
\hline 3 & Kuisioner di kelas Regular C & 5 & 5 & 5 \\
\hline \multicolumn{6}{|}{ Total kuisioner yang dapat diolah } & 25 & 25 & 25 \\
\hline
\end{tabular}

Pilot Test Sample

\subsection{Results}

\subsubsection{Data Quality Test}

1) Validity Test

the number of sample (n) in the study are 75 respondents with a significant level 0.05 with $\mathrm{df}=\mathrm{n}-2$, then $\mathrm{df}=75-2=73$. $\mathrm{r}$ table is 0.2272 . In the study also all variables of each indicator has $r$ observe $>r$ table then the questionnaire and the indicator has a valid result.

2) Reliability Test

Based on observation that has been conducted, all variables have Cronbach's Alpha> 0.70 then the indicator or questionnaire on the variable of Spiritual Intelligence (SQ), Personality Type and Auditor's Ability to Detect Fraud is reliable.

\subsubsection{Classical Assumption Test}

1) Multicollinearity Test

Based on observation that has been conducted, it shows that all independent variables has a Tolerance value $1,000 \geq 0.10$ and VIF value $1,000 \leq 10$. Thus, it can be concluded that all independent variables in the study do not have multicollinearity.

2) Normality Test

The value of Kolmogorov-Smirnov is 0.087 and significant $0.200>\alpha$ (the value of $\alpha$ is $5 \%$ ). This indicates that Ho: normally distributed data is received

3) Heteroscedasticity Test 


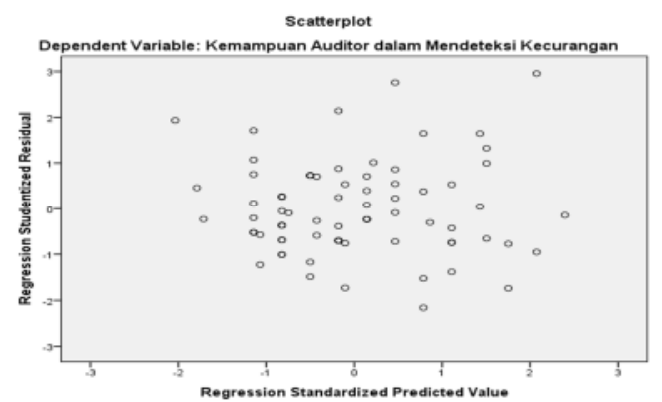

From the scatterplot chart above, it is seen that the dots spread randomly and spread above and below the number 0 (zero) on the ordinat. Consequently, It can be concluded that there is no heteroscedasticity in the regression model of the study.

\subsubsection{Hypothesis Test}

1) Hypotheses Test Result 1

Based on observation that has been conducted, adjusted R2 is 0.192. It means $19.2 \%$ dependent variable ability to detect fraud explained by the variable of personality type and spiritual intelligence while the remaining $80.8 \%$ can be explained by other variables. Thus, the first hypothesis that Spiritual Intelligence affects the Ability to Detect Fraud is accepted.

2) Hypotheses Test Result 2

Based on observation that has been conducted, Spiritual Intelligence has a significance value of 0.000 on the table above. It shows that Spiritual Intelligence significantly affects the Ability to Detect Fraud. This is caused by the significance value of 0.000 is smaller than the value of $\alpha=5 \%(0.005)$.

Personality Type has no significant effect on Auditor's ability to Detect Fraud This is caused by the value of significance of 0.654 is greater than the value of $\alpha=5 \%(0.005)$. Thus, hypothesis 2 which states that the Personality Type ST and NT affect the ability to detect draud is rejected.

3) Hypotheses Test Result 3

Based on table above, it can be seen that the value of $\mathrm{F}$ observe is 9.779 with a significance level 0.000. Since the level of significance is less than 0.05 , it can be said that spiritual intelligence and personality type influence simultaneously and significantly affect to the ability to detect fraud. Hence, hypothesis 3 which states that the personality type and spiritual intelligence affect simultaneously to the ability to detect fraud is accepted.

\subsection{Discussion}

\subsubsection{The Effect of Spiritual Diligence (SQ) on Auditor's Ability to Detect Fraud}

Based on the result of significance tests of $\mathrm{H} 1$ in the study which states that the effect of Spiritual Intelligence significantly affects the auditor's ability to detect fraud. The results of the study support the research conducted by Fauzan (2016) which mentioned that Spiritual Intelligence significantly affects the auditor's ability to detect fraud. Spiritual intelligence guides people to express and 
give meaning to their actions, then it can be concluded that to improve the auditor's ability to detect fraud an auditor must be able to adapt to stressful situations, focus on contributing in optimizing responsibilities as an auditor and always thinking positively.

\subsubsection{The Effect of Personality Type on Auditor's Ability to Detect Fraud}

Based on the results of statistical tests, itu can be concluded that $\mathrm{H} 2$ in this study ST and NT personality types have no significant effect on the auditor's ability to detect fraud. The result of this research is similar to the research conducted by Gusti Ayu Yupin N.R (2017) which stated that the difference of personality type ST and NT owned by the auditor does not affect the auditor's ability to detect fraud. This may be caused by auditors have competencies that make auditors faster and more precise to detect fraud.

\subsubsection{The Effect of Spiritual Intelligence (SQ) and Personality Type to Auditor's Ability to Detect Fraud}

Spiritual intelligence serves as a controller of other intelligences that has not been optimized their performance yet (Yudono, 2008 :36). The manifestation of the intelligence is the moral attitude which is considered by the performer. Personality type is also determined by the moral attitude and ability of a person in solving a problem and in deciding good decisions. All these factors simultaneously affect the Auditor's Ability to Detect Fraud.

\section{CONCLUSION}

The study is conducted to test whether spiritual intelligence and personality type affect the ability of auditors to detect fraud. Based on the results of the Observation that has been conducted, it can be concluded that spiritual intelligence significantly affects the auditor's ability to detect fraud, while the personality type has no significant effect on the auditor's ability to detect fraud, and spiritual spirit and personality type simultaneously and significantly affect the auditor's ability to detect fraud.

\section{REFERENCES}

Abdullah, Omar, R \& Panarik, SA. (2016). A literature review on personality, creativity and innovative behavior' International Review of Management and Marketing. Vol 6, no. 1, pp. 177-182.

Agoes, Sukrisno. (2012). Auditing Petunjuk PraktisPemeriksaan Akuntan Oleh Akuntan Publik. Jilid 1, Edisi Keempat, Salemba Empat, Jakarta.

Arens, Alvin A., Randal J. Elder, Mark S.Beasley, dan Amir Abadi Jusuf.. (2011) Auditing dan Jasa Assurance. Buku 1, Jakarta: Salemba Empat. 
Arikunto. (2010). Prosedur Penelitian : Suatu Pendekatan Praktek. Jakarta: Rineka Cipta.

Arsendy, Muhammad Teguh. (2017). Pengaruh Pengalaman Audit, Skeptisme Profesional, Red Flags, dan Tekanan Anggaran Waktu Terhadap Kemampuan Auditor dalam Mendeteksi Kecurangan. Vol. 4, No. 1.

Choiriah, Anis. (2013). Pengaruh Kecerdasan Emosional, Kecerdasan Intelektual, Kecerdasan Spiritual, dan Etika Profesi Terhadap Kinerja Auditor dalam Kantor Akuntan Publik (Studi empiris pada Auditor dalam Kantor Akuntan Publik di Kota Padang dan Pekanbaru). Universitas Negeri Padang.

Dharmawan, Nyoman Ari Surya. (2013). Pengaruh Kecerdasan Intelektual, Kecerdasan Emosional, dan Kecerdasan Spiriual pada Profesionalisme Kerja Auditor. Vol. 2, No. 2. Universitas Pendidikan Ganesha.

Fauzan, Muhammad Fadjar Arif. (2017). Pengaruh Kecerdasan Emosional, Kecerdasan Spiritual, dan Tekanan Klien Terhadap Kualitas Audit. (Studi Empiris pada Kantor Akuntan Publik di Yogyakarta). Universitas Negeri Yogyakarta.

Firdaos, Rizal. (2016). Metode Pengembangan Intrumen Pengukur Kecerdasan Spiritual Mahasiswa. Vol. 11, No. 2. IAIN Raden Intan Lampung.

Fonda, Ausella Jean. (2014). Pengaruh Tekanan Anggaran Waktu, Tipe Kepribadian Auditor, Independensi dan Kompetensi Terhadap Kualitas Audit (Studi Empiris pada Auditor KAP di Semarang). Universitas Diponegoro.

Ghozali, Imam. (2016). Aplikasi Analisis Multivariate dengan Program IBM SPSS 2, Edisi 8, Universitas Diponegoro, Semarang.

Ghozali, Imam. (2009). Aplikasi Analisis Multivariate dengan Program SPSS. Semarang : UNDIP.

Ismail, Fikri. (2015). Pengaruh Tipe Kepribadian, Pengalaman Difungsional Terhadap Audit Judgment. Vol. 5, No. 2. Ikatan Akuntansi Indonesia.

Kuncoro, Mudrajad. (2013). Metode Riset untuk Bisnis \& Ekonomi, Edisi Ketiga, Jakarta: Penerbit Erlangga.

Khairat, Hayatul. (2017). Pengaruh Kecerdasan Emosional, Kecerdasan Intelektual, Kecerdasan Spiritual dan Komitmen Organisasi Terhadap Kinerja Audit. Universitas Riau.

Pasek, Nyoman Suadnyana. (2016). Pengaruh Kecerdasan Intelektual pada Pemahaman Akuntansi dengan Kecerdasan Emosi dan Kecerdasan Spiritual Sebagai Variabel Pemoderasi. Vol. 1, No. 1. Universitas Pendidikan Ganesha.

Mulyadi. (2011). Sistem Perencanaan dan Pengendalian Manajemen. Jakarta: Salamba Empat, 2011.

Nasution, Hafifah dan Fitriyani. (2012). Pengaruh Beban Kerja, Pengalaman Audit dan Tipe Kepribadian Terhadap Skeptisme Profesional dan Kemampuan Auditor dalam Mendeteksi Kecurangan ( Studi kasus Kantor Akuntan Publik di wilayah Jakarta). Universitas Islam Negeri Syarif Hidayatullah. 
Rachmi, Filian. (2010). Pengaruh Kecerdasan Emosional, Kecerdasan Spiritual, dan Prilaku Belajar Terhadap Pemahaman Akuntansi. Semarang. Jurnal Pendidikan Akuntansi.

Ranu, Gusti Ayu Yupin Nia dan Luh Komang Merawati. (2017). Kemampuan Mendetaksi Fraud Berdasarkan Skeptisme Profesional, Beban Kerja, Pengalaman Audit dan Tipe Kepribadian Auditor. Universitas Mahasarawati.

Resmawati, Irma. (2015). Pengaruh Kecerdasan Spiritual, Kecerdasan Emosional dan Kecerdasan Intelektual terhadap Kemampuan Mendeteksi Kecurangan” (Studi pada 10 Kantor Akuntan Publik di Kota Bandung). Universitas Pasudan Bandung.

Utama, Arya. (2010). Ilmu Psikologi, Ilmu Bimbingan dan Konseling, dan Ilmu Pengembangan Diri. Jakarta.

Santikawati, Anak Agung Putri, dan Bambang Suprasto H. (2016). Kecerdasan Spiritual Sebagai Pemoderasi Locus Control Internal dan Gaji Auditor pada Kinerja Auditor. Vol. 16.(1), Universitas Udayana.

Setiawan, Yuliana Greece. (2016). Pengaruh Kecerdasan Emosional, Kecerdasan Spiritual, Kecerdasan Intelektuan dan Independensi Pada Kinerja Auditor. Universitas Udayana.

Suminta, Rini Risnawita. (2016). Hubungan Antara Tipe Kepribadian Dengan Orientasi Religiusitas. Jurnal Ilmu Aqidah dan Studi Keagamaan Vol. 4, No. 2.

Supriyanto. (2014). Pengaruh Beban Kerja, Pengalaman Audit, Tipe Kepribadian dan Skeptisme Profesional Terhadap Kemampuan Auditor dalam Mendeteksi Kecurangan (Studi Empiris pada Kantor Akuntan Publik di kota Solo dan Yogyakarta). Universitas Muhammadiyah Surakarta.

Suryanto, Rudi, Yosita Indriyani, dan Hafiez Sofyani. (2017). Determinasi Kemampuan Auditor dalam Mendeteksi Kecurangan. Vol. 18 No. 1, Hal: 102-118.

Swari, A. Putu Candra Mitha dan Wayan Ramantha. (2013). Pengaruh Independensi dan Tiga Kecerdasan Terhadap Pertimbangan Pemberian Opini Auditor. Bali : Fakultas Ekonomi Universitas Udayana.

Winarni, Restu. (2015). Pengaruh Karakteristik Tipe Kepribadian dan IPK Terhadap Kecemasan Berkomputer Mahasiswa Akuntansi dalam Menggunakan Software Akuntansi dengan Lucus of Control Sebagai Variabel Moderasi (Studi kasus pada mahasiswa program studi akuntansi fakultas ekonomi Universitas Negeri Yogyakarta). Universitas Negeri Yogyakarta.

Yusriyanti, Hasni. (2015). Pengaruh Pengalaman Audit, Beban Kerja, Teks Specific Knowledge Terhadap Pendeteksian Kecurangan Laporan Keuangan (Studi Pada KAP di Sumatra Bagian Selatan). Vol. 13 No.1. Universitas Sriwijaya.

Zohar, D \& Marshall. (2001). Memanfaatkan Kecerdasan Spiritual Dalam Berfikir Intergralistik dan Holistik untuk Memaknai Kehidupan. (Cetakan I) Mizan Pustaka, Bandung. 